\title{
TATA LAKSANA KELAHIRAN NEONATUS DARI IBU YANG TERKAIT COVID-19
}

\author{
Daniel Christianto ${ }^{1}$ \\ ${ }^{1}$ Pendidikan Dokter, Fakultas Kedokteran, Universitas Lampung
}

\begin{abstract}
Management of Neonatal Birth to Mothers Related to COVID-19. COVID-19 (Coronavirus disease 2019) has been declared a pandemic case. This disease can also affect women who are pregnant, and children of all ages. Of course, this requires special attention, especially for a baby to be born from a mother related to COVID-19. This text outlines the steps for the management of neonatal birth from mothers suspected or confirmed of COVID-19. The purpose of writing this manuscript is to conduct a quick and precise review by a health practitioner to ensure the best care for newborns. The use of antenatal steroids should consider the benefits and potential dangers for the fetus and pregnant patients. In summary, neonates born to mothers with COVID-19 took them according to appropriate procedures, and followed further discussion on SARS-CoV2 and COVID-19. Meanwhile, women with a COVID-19 test that is delayed during labor should consider the person being investigated for infection.
\end{abstract}

Keywords : Neonatal birth, Corona virus disease 2019 (COVID-19), personal protective equipment (PPE)

Abstrak: Tata Laksana Kelahiran Neonatus dari Ibu yang Terkait COVID-19. COVID-19 (Corona virus disease 2019) telah dinyatakan sebagai kasus pandemi. Penyakit ini juga dapat menyerang ibu yang sedang hamil, dan anak dari segala usia. Tentu hal ini membutuhkan perhatian khusus, terutama bagi seorang bayi yang akan dilahirkan dari ibu terkait COVID-19. Naskah ini menguraikan langkahlangkah tata laksana kelahiran neonatus dari ibu yang dicurigai atau dikonfirmasi COVID-19. Tujuan penulisan naskah ini adalah melakukan tinjauan yang cepat dan tepat oleh praktisi kesehatan untuk memastikan perawatan terbaik bagi bayi baru lahir. Penggunaan steroid antenatal hendaknya mempertimbangkan manfaat dan potensi bahayanya bagi janin dan pasien hamil. Ringkasannya, neonatus yang lahir dari ibu dengan COVID-19 hendaknya dilahirkan dengan alur tata laksana yang sesuai, dan mengikuti pembaruan lebih lanjut tentang SARS-CoV-2 dan COVID-19. Sementara itu, ibu dengan tes COVID-19 yang tertunda saat persalinan harus dianggap sebagai orang yang sedang diselidiki untuk infeksi.

Kata Kunci : Kelahiran neonatus, Corona virus disease 2019 (COVID-19), alat pelindung diri (APD)

\section{PENDAHULUAN}

Penyakit COVID-19 adalah infeksi saluran pernapasan yang disebabkan oleh coronavirus, dan muncul pertama kali di Wuhan, Tiongkok pada bulan Desember 2019. Virus ini merupakan jenis dari betacoronavirus yang terkait erat dengan virus SARS. Sekitar $14 \%$ orang yang terjangkit COVID-19 menderita penyakit parah sehingga membutuhkan perawatan rumah sakit, dukungan oksigen, dan 5\% diantaranya masuk ke unit perawatan intensif (Team NCPERET, 2020).

Perubahan fisiologis selama kehamilan, seperti penurunan volume residu fungsional, peningkatan 
diafragma, dan perubahan sel imun menyebabkan peningkatan kerentanan terhadap infeksi virus (Dashraath et al., 2020). Virus corona yang bertanggung jawab atas terjadinya Severe Acute Respiratory Syndrome (SARS) dan Middle East Respiratory Syndrome (MERS) juga dapat menyebabkan hasil kehamilan buruk, seperti keguguran, kelahiran prematur, pembatasan pertumbuhan intrauterin, dan kematian ibu (Alfaraj, Al-Tawfiq, \& Memish, 2019). Pada SARS dan MERS, sebanyak $35 \%$ hingga $41 \%$ dari pasien hamil membutuhkan ventilasi mekanis, dan angka kematian masing-masing mencapai $18 \%$ dan $25 \%$ (Alzamora et al., 2020). Sebaliknya, mayoritas kasus COVID-19 yang dilaporkan pada pasien hamil menunjukkan perjalanan penyakit yang ringan atau tanpa gejala, dengan hanya beberapa kasus yang membutuhkan perawatan di unit perawatan intensif, dan hanya beberapa kasus yang dilaporkan membutuhkan ventilasi mekanis (Liu et al., 2020; Iqbal et al., 2020; Breslin et al., 2020).

Beberapa kasus menunjukkan bahwa penularan perinatal ke bayi baru lahir dari wanita terinfeksi COVID-19 dapat terjadi. Data pediatrik menunjukkan bahwa anak bahwa anakanak dari segala usia rentan terhadap SARS-CoV-2, bahkan bayi di bawah usia 1 tahun berisiko terkena penyakit parah meskipun relatif jarang terjadi (Korraa, 2020). Oleh karena itu, setiap wanita hamil dengan riwayat epidemiologis kontak harus dimonitor dengan hati-hati (WHO, 2020).

Wanita hamil yang bepergian ke negara yang terkena SARS-CoV-2 dalam 14 hari sebelumnya atau yang telah melakukan kontak dengan pasien terinfeksi SARS-CoV-2 yang dikonfirmasi, harus diuji dengan tes amplifikasi asam nukleat SARS-CoV-2, bahkan jika tanpa gejala. Wanita hamil dengan infeksi SARS-CoV-2 yang dikonfirmasi pemeriksaan laboratorium, harus dipantau di rumah untuk untuk gambaran klinis COVID-19 setidaknya 14 hari walaupun tidak menunjukkan gejala. Pasien seperti ini dan mereka yang pulih dari penyakit ringan harus dipantau dengan ultrasound pertumbuhan janin setiap dua bulan, serta penilaian Doppler karena risiko potensial dalam pembatasan pertumbuhan intrauterin. Wanita hamil dengan COVID-19 pneumonia harus dirawat oleh tim multidisiplin di pusat perawatan tersier. Ketika kriteria penilaian kegagalan organ terkait sepsis terpenuhi, pasien harus dipindahkan ke unit perawatan intensif (Favre et al., 2020).

Ada ketidakpastian mengenai potensi penularan vertikal atau perinatal SARS-CoV-2 dari wanita hamil yang terinfeksi ke bayi mereka (Queensland Government, 2020). Hasil uji RT-PCR cairan amniotik, darah tali pusat, serta apusan tenggorok bayi dari enam ibu positif COVID-19 yang dilahirkan dengan cara bedah sesar, semuanya menyatakan hasil negatif virus COVID-19 (Chen et al., 2020; Zhu et al., 2020). Sementara itu, terdapat laporan kasus yang menyatakan hasil positif pada RT-PCR dari swab nasofaring neonatal 16 jam segera setelah lahir. Rendahnya tingkat infeksi selama operasi sesar atau postnatal dapat terjadi karena sterilitas prosedur dan langkah isolasi yang dilaksanakan segera setelah lahir. Hal itu meningkatkan kecurigaan transmisi dalam SARS-CoV-2 dalam rahim sehingga wanita hamil harus dianggap sebagai populasi yang rentan dan berisiko tinggi (Alzamora et al., 2020).

\section{METODE}

Metode yang digunakan berupa studi pustaka yang didasarkan atas hasil studi terhadap berbagai literatur yang telah teruji validitasnya, dan relevan dengan kajian penulisan, serta mendukung analisis pembahasan. Informasi yang didapatkan bersumber dari berbagai referensi atau literatur yang relevan dengan topik permasalahan yang dibahas. Validitas dan relevansi referensi yang digunakan dapat dipertanggungjawabkan. 


\section{PEMBAHASAN}

Penggunaan Steroid Antenatal:

Steroid antenatal dikenal dapat mempercepat pengembangan sel-sel alveolar tipe-2 di paru-paru, di mana sel ini kaya akan angiotensin-converting enzyme-2. ACE-2 ini adalah reseptor SARS-CoV fungsional in vitro dan in vivo (Korraa, 2020). Namun, teori ini diimbangi dengan adanya penurunan signifikan terhadap mortalitas dan morbiditas pada bayi prematur yang menerima steroid antenatal. Saat ini, tidak ada bukti yang mendukung atau membantah penggunaan steroid antenatal pada ibu dengan COVID-19 dan kelahiran prematur mendatang (Chandrasekharan et al., 2020). Sementara itu, adanya manfaat yang jelas dari pemberian steroid antenatal antara $24+0$ dan $33+6$ minggu kehamilan pada pasien dengan risiko tinggi kelahiran prematur dalam tujuh hari, mengakibatkan American College of Obstetricians and Gynaecologists (ACOG) merekomendasikan penggunaannya sebagai indikasi standar untuk pasien hamil dengan dugaan atau konfirmasi COVID-19 (ACOG, 2020). Terkait pasien hamil yang dicurigai atau dikonfirmasi COVID-19 pada $34+0$ hingga $36+6$ minggu kehamilan dan berisiko lahir prematur dalam waktu tujuh hari, tidak didapatkan manfaat yang jelas bagi neonatus sehingga ACOG menyarankan untuk tidak memberikan betamethasone pada pasien tersebut (Queensland Government, 2020). Akan tetapi, keputusan ini perlu disesuaikan secara individu, dengan menimbang manfaat bagi neonatal dan potensi bahaya pada pasien hamil (Korraa, 2020).

Alur Tatalaksana Kelahiran

Neonatus: Kelahiran neonatus dari ibu yang terkait COVID-19 harus dilakukan di ruang isolasi khusus untuk COVID-19. Pada periode golden hour baik untuk ibu hamil ODP, PDP, serta probabel dan konfirmasi COVID-19, kegiatan resusitasi, stabilisasi, dan transport dilakukan sesuai panduan prosedur klinis di ruang isolasi khusus COVID-19, di mana tim resusitasi harus menggunakan APD tingkat perlindungan
III. Pada kondisi bayi bugar, observasi dan perawatan dilanjutkan di ruang transisi isolasi khusus COVID-19. Pada kondisi bayi mengalami asfiksia neonatorum, perawatan neonatus dilanjutkan di unit perawatan intensif neonatal (UPIN) isolasi khusus COVID19 dengan tim khusus COVID-19 berdasarkan panduan prosedur klinis masing-masing rumah sakit, dengan kapasitas pelayanan neonatal yang sesuai tingkat kompetensinya (Burhan dkk, 2020). Royal College of Obstetricians and Gynaecologists (RCOG) merekomendasikan bahwa setelah bayi baru lahir dalam keadaan stabil maka bayi harus dimandikan dengan air dan sabun untuk menghilangkan virus yang berpotensi terletak pada permukaan kulit sebelum dipindahkan ke ruang ICU (RCOG, 2020).

Periode transisi intra menuju ekstrauteri (0 - 6 jam pasca lahir), di ruang transisi isolasi khusus COVID19:

Pada keadaan neonatus bugar, yakni nafas spontan, tonus baik, dan denyut jantung $>100 \mathrm{kali} / \mathrm{menit}$ maka petugas menggunakan APD tingkat perlindungan I dan dilakukan perawatan neonatal esensial, tanpa inisiasi menyusu dini. Pada kegawatan neonatus, yakni sianosis, perdarahan, ikterus, muntah bilier, dan kejang maka petugas menggunakan APD tingkat perlindungan II, lalu neonatus dipindahkan ke UPIN isolasi khusus COVID-19 (Burhan dkk, 2020). Kehadiran ibu yang positif COVID-19 saat persalinan tidak disarankan secara rutin bila tanpa indikasi lain gawat janin dan atau kebutuhan yang perlu diantisipasi untuk resusitasi lanjutan. Jika tim resusitasi neonatal diperlukan, hanya personel penting dan berpengalaman yang harus hadir dengan tetap menjaga jarak dua meter dari ibu (Korraa, 2020). Stabilisasi dan resusitasi neonatus dapat dilakukan di ruang yang berdekatan atau tempat yang sama dengan jarak minimal enam kaki atau dua meter dari ibu, disertai 
penghalang fisik, seperti tirai diantaranya (Chandrasekharan et al., 2020). Pemeriksaan swab dan sediaan darah bayi dilakukan pada hari ke-1 dan ke-14 untuk pemeriksaan SARS-CoV-2 (Burhan dkk, 2020). ASI hanya digunakan oleh bayi tersebut dan dilakukan pembersihan pompa setelah digunakan. Kebersihan peralatan untuk memberikan ASI perah harus diperhatikan. Bayi dimonitor secara ketat dan perlu dipantau hingga pulang. Dukungan kesehatan mental dan psikososial diberikan untuk ibu dan keluarga (Burhan dkk, 2020).

Periode perineonatal 6 jam hingga 14 hari pasca lahir di ruang isolasi khusus COVID-19:

Neonatus masuk dalam kriteria kontak erat risiko tinggi maka tidak dilakukan rawat gabung, melainkan dirawat terpisah dari ibu di ruang isolasi khusus COVID-19 di mana petugas menggunakan APD tingkat perlindungan II. Pada keadaan neonatus selanjutnya, ASI tetap diberikan kepada bayi dalam bentuk ASI perah. Pompa ASI hanya digunakan oleh ibu tersebut dan dilakukan pembersihan pompa setelah digunakan. Kebersihan peralatan untuk memberikan ASI perah harus diperhatikan. Dukungan kesehatan mental dan psikososial diberikan untuk ibu dan keluarga. Bayi dimonitor secara ketat dan dipantau hingga dipulangkan setelah 14 hari. Jika bayi menunjukkan gejala, maka bayi dirawat sebagai PDP di UPIN isolasi khusus COVID-19. Perawatan bayi terpisah dari ibu hingga ibu dinyatakan sembuh oleh dokter yang merawat sesuai dengan kriteria yang berlaku (Burhan dkk, 2020). Periode perineonatal $3-28$ hari pasca lahir di rumah, isolasi neonatus dari siapapun yang sakit dan periode perineonatal $14-28$ hari pasca lahir di ruang isolasi khusus COVID-19:

Pada keadaan neonatal sehat dari ibu yang dinyatakan sehat, bayi mendapatkan perlakuan normal dan dilakukan kontrol bayi sehat sesuai jadwal. Sementara itu, pada keadaan neonatal sehat dari ibu yang dinyatakan tidak sehat, bayi mendapatkan perlakuan seperti di rumah sakit.
Apabila neonatus sakit maka segera dibawa ke rumah sakit terdekat (Burhan dkk, 2020). 2020):

Rekomendasi Persalinan (POGI,

1. Jika seorang ibu dengan COVID-19 dirawat di ruang isolasi di ruang bersalin, maka dilakukan penanganan tim multidisiplin yang terkait, meliputi dokter paru/penyakit dalam, dokter kandungan, anestesi, bidan, dokter neonatologis, dan perawat neonatal.

2. Upaya harus dilakukan untuk meminimalkan jumlah anggota staf yang memasuki ruangan dan unit harus mengembangkan kebijakan lokal yang menetapkan personil yang ikut dalam perawatan. Hanya satu orang (pasangan/anggota keluarga) yang dapat menemani pasien. Orang yang menemani pasien harus diinformasikan mengenai risiko penularan dan mereka harus memakai APD yang sesuai.

3. Pengamatan dan penilaian ibu harus dilanjutkan sesuai praktik standar, dengan penambahan saturasi oksigen yang bertujuan untuk menjaga saturasi oksigen > $94 \%$, titrasi terapi oksigen sesuai kondisi.

4. Menimbang kejadian penurunan kondisi janin pada beberapa laporan kasus di Cina, apabila sarana memungkinkan dilakukan pemantauan janin secara berkelanjutan selama persalinan.

5. Hingga saat ini belum ada bukti klinis kuat yang merekomendasikan salah satu cara persalinan sehingga persalinan dilakukan berdasarkan indikasi obstetri dengan memperhatikan keinginan ibu dan keluarga, kecuali ibu dengan masalah gangguan respirasi yang memerlukan persalinan segera berupa seksio, maupun tindakan operatif pervaginam.

6. Bila ada indikasi induksi persalinan pada ibu hamil dengan PDP atau konfirmasi COVID-19, dilakukan 
evaluasi urgensi, dan apabila memungkinkan untuk ditunda hingga infeksi terkonfirmasi atau keadaan akut sudah teratasi. Jika situasi menunda dianggap tidak aman, maka induksi persalinan dilakukan di ruang isolasi termasuk perawatan pasca persalinan.

7. Bila ada indikasi operasi terencana pada ibu hamil dengan PDP atau konfirmasi COVID-19, dilakukan evaluasi urgensi, dan apabila memungkinkan untuk ditunda bertujuan mengurangi risiko penularan hingga infeksi terkonfirmasi atau keadaan akut sudah teratasi. Apabila operasi tidak dapat ditunda maka operasi berdasarkan prosedur standar dengan pencegahan infeksi sesuai standar APD yang lengkap.

8. Persiapan operasi terencana dilakukan sesuai standar.

9. Apabila dalam persalinan ibu mengalami perburukan gejala maka dipertimbangkan keadaan secara individual untuk melanjutkan observasi persalinan atau dilakukan operasi sesar darurat jika hal ini akan memperbaiki usaha resusitasi ibu.

10. Pada ibu dengan persalinan kala II dipertimbangkan tindakan operatif pervaginam untuk mempercepat kala II pada ibu dengan gejala kelelahan ibu atau adanya tanda hipoksia.

11. Perimortem caesarean section dilakukan sesuai standar apabila ibu dengan kegagalan resusitasi, tetapi janin masih viabel.

12. Ruang operasi kebidanan:

a. Operasi elektif pada pasien COVID-19 harus dijadwalkan terakhir.

b. Pasca Operasi, ruang operasi harus dilakukan pembersihan penuh ruang sesuai standar.

c. Jumlah petugas di kamar seminimal mungkin dan menggunakan alat pelindung diri sesuai standar.

13. Penjepitan tali pusat ditunda atau beberapa saat setelah persalinan masih bisa dilakukan asalkan tidak ada kontraindikasi lainnya. Bayi dapat dibersihkan dan dikeringkan seperti biasa, sementara tali pusat masih belum dipotong. RCOG membuat rekomendasi untuk perawatan wanita dengan COVID19 pada tahap persalinan dengan menekankan bahwa keterlambatan penutupan tali pusat tidak dianjurkan (terutama untuk ibu yang tidak sehat) dan harus didiskusikan dengan ibu, tidak melakukan tindakan kontak kulit ke kulit antara ibu dan bayi, melakukan isap hidung bayi sebelum napas pertama, dan mengisolasi bayi segera setelah lahir, serta melakukan tes coronavirus untuk bayi itu (Favre et al., 2020).

14. Staf layanan kesehatan di ruang persalinan harus mematuhi Standard Contact dan Droplet Precautions termasuk menggunakan APD sesuai dengan panduan Pencegahan dan Pengendalian Infeksi (PPI).

15. Antibiotik intrapartum harus diberikan sesuai protokol.

16. Plasenta harus dilakukan penanganan sesuai praktik normal. Jika diperlukan histologi, jaringan harus diserahkan ke laboratorium, dan pihak laboratorium harus diberitahu bahwa sampel berasal dari pasien suspek atau terkonfirmasi COVID-19.

17. Berikan anestesi epidural atau spinal sesuai indikasi dan hindari anestesi umum, kecuali benarbenar diperlukan.

18. Tim neonatal harus diberitahu sebelumnya mengenai rencana untuk melahirkan bayi dari ibu yang terkena COVID-19.

2020):

Rekomendasi Postpartum (POGI,

1. Karena informasi mengenai virus ini terbatas dan belum ada profilaksis atau pengobatan yang tersedia, pilihan untuk perawatan bayi harus didiskusikan dengan keluarga pasien dan tim kesehatan yang berkaitan. 
2. Ibu dikonseling tentang adanya referensi dari Cina yang menyarankan isolasi terpisah antara ibu yang terinfeksi dengan bayinya selama 14 hari. Pemisahan sementara ini bertujuan untuk mengurangi kontak antara ibu dan bayi.

3. Bila seorang ibu menunjukkan bahwa ia ingin merawat bayi sendiri, maka segala upaya harus dilakukan untuk memastikan bahwa ibu telah menerima informasi lengkap dan memahami risiko terhadap bayi.

4. Hingga saat ini, data terbatas untuk memandu manajemen postnatal bayi dari ibu yang positif COVID-19 pada trimester ketiga kehamilan. Belum ditemukan bukti transmisi vertikal (antenatal).

5. Semua bayi yang lahir dari ibu dengan PDP atau dikonfirmasi COVID-19 perlu diperiksa COVID19.

Neonatus lahir dari ibu hamil PDP COVID-19

(Tata laksana observasi, persalinan dan bedah sesar di ruang isolasi khusus untuk persalinan dan bedah sesar ibu terkait COVID-19)

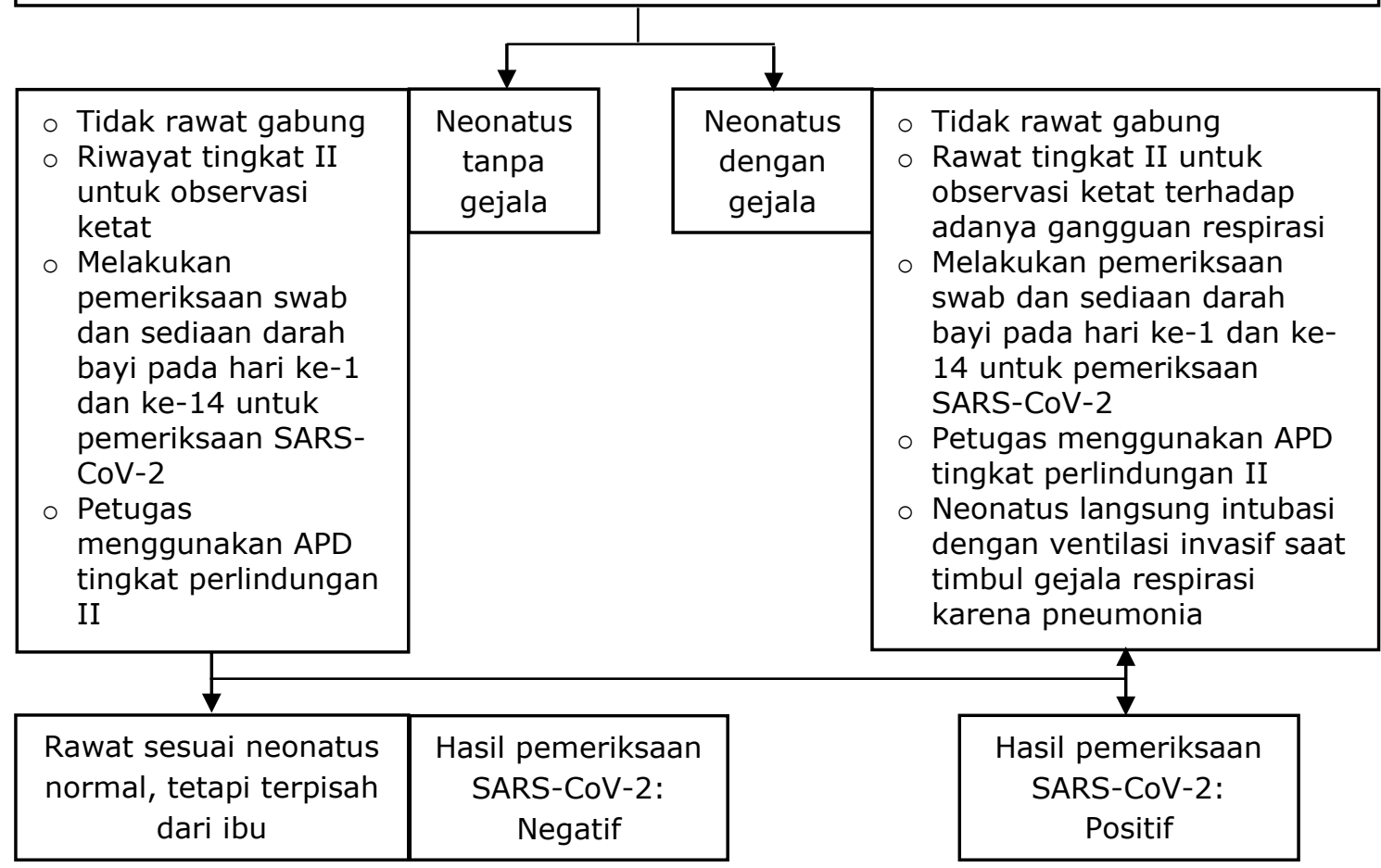

Gambar 1. Algoritma Kelahiran Neonatus dari Ibu Hamil PDP COVID19 (WHO, 2020).

6. Bila ibu memutuskan untuk merawat bayi sendiri maka baik ibu dan bayi harus diisolasi dalam satu kamar dengan fasilitas en-suite selama dirawat di rumah sakit. Tindakan pencegahan tambahan yang disarankan adalah sebagai berikut.

a. Bayi harus ditempatkan di inkubator tertutup di dalam ruangan. b. Ketika bayi berada di luar inkubator dan ibu menyusui, mandi, merawat, memeluk, atau berada dalam jarak satu meter dari bayi, maka ibu disarankan untuk menggunakan APD yang sesuai dengan pedoman PPI dan diajarkan mengenai etika batuk.

c. Bayi harus dikeluarkan sementara dari ruangan jika ada prosedur yang menghasilkan aerosol yang harus dilakukan di dalam ruangan. 
7. Pemulangan untuk ibu postpartum harus mengikuti rekomendasi pemulangan pasien COVID-19.

Perawatan Neonatus terkait COVID19 (Burhan dkk, 2020):

1. Pada perawatan tingkat II, dilakukan isolasi khusus untuk mencegah penularan secara droplet dan airborne dengan memperhatikan sirkulasi udara. Petugas yang merawat menggunakan APD tingkat perlindungan II.

2. Pada perawatan tingkat III (UPIN), dilakukan isolasi khusus untuk mencegah penularan secara droplet dan airborne dengan memperhatikan sirkulasi udara. Petugas yang merawat menggunakan APD tingkat perlindungan II. Kemudian, dilakukan isolasi khusus sistem pernapasan neonatus dengan tidak memberikan terapi oksigen menggunakan ventilasi non-invasif. Apabila terapi oksigen diperlukan, dapat diberikan melalui ventilasi invasif dengan perlindungan ketat pada tenaga medis dalam melakukan pembersihan jalan napas dan intubasi. Tim resusitasi menggunakan APD tingkat perlindungan III.

\section{KESIMPULAN}

Perubahan fisiologis selama kehamilan dapat menyebabkan peningkatan kerentanan terhadap infeksi virus, termasuk coronavirus. Wanita hamil yang bepergian ke negara yang terkena SARS-CoV-2 dalam 14 hari sebelumnya atau yang telah melakukan kontak dengan pasien terinfeksi SARS-CoV-2 yang dikonfirmasi, harus diuji dengan tes amplifikasi asam nukleat SARS-CoV-2 walaupun tanpa gejala. Penelitian mengenai potensi penularan vertikal atau perinatal SARS-CoV-2 dari wanita hamil yang terinfeksi ke bayi mereka masih terus dilakukan.

Penggunaan steroid antenatal bagi wanita hamil harus mempertimbangkan manfaat dan potensi bahaya terhadap janin dan wanita hamil tersebut. Kelahiran neonatus dari ibu yang terkait COVID-19 harus dilakukan di ruang isolasi khusus untuk COVID-19 dengan terus memperhatikan periode golden hour, kondisi bayi, dan keadaan setiap periode pasca lahir seperti pada periode transisi intra menuju ekstrauteri, perinatal, dan perineonatal. Algoritma dan rekomendasi saat persalinan dan postpartum juga perlu diperhatikan. Hal ini bertujuan untuk mencegah penularan pada bayi baru lahir dan tenaga medis yang bertugas.

\section{DAFTAR PUSTAKA}

Alfaraj, S.H., Al-Tawfiq, J.A., \& Memish, Z.A. (2019). Middle East respiratory syndrome coronavirus (MERS-CoV) infection during pregnancy: report of two cases \& review of the literature. Journal of Microbiology, Immunology and Infection, 52, 501-503.

Alzamora, M.C., et al. (2020). Severe COVID-19 during Pregnancy and Possible Vertical Transmission. American Journal of Perinatology, 1(212), 861-865.

American College of Obstetricians and Gynecologists (ACOG). (2020). COVID-19 FAQs for ObstetricianGynecologists, Obstetrics. Washington DC, American College of Obstetricians and Gynecologists. Dari

https://www.acog.org/clinicalinformation/physician-fags/COVID19-faqs-for-ob-gyns-obstetrics, dilihat pada tanggal 13 Juli 2020.

Breslin, N. et al. (2020). COVID-19 in pregnancy: early lessons. American Journal of Obstetrics \& Gynecology MFM, 2(2).

Burhan, E., dkk. (2020). Protokol Tatalaksana COVID-19 Edisi 1. PDPI, PERKI, PAPDI, PERDATIN, IDAI. Dari

http://www.inaheart.org/perki/upl oad/files/Protokol\%20Tatalaksana $\% 20$ COVID19\%2050P\%20FINAL(4).pdf, diunduh pada tanggal 29 Juni 2020. 
Chandrasekharan, P., et al. (2020). Neonatal Resuscitation and Postresuscitation Care of Infants Born to Mothers with Suspected or Confirmed SARS-CoV-2 Infection. American Journal of Perinatology, 37(8), 813-824.

Chen, H., et al. (2020). Clinical characteristics and intrauterine vertical transmission potential of COVID-19 infection in nine pregnant women: a retrospective review of medical records. The Lancet, 395(10226), 809-815.

Dashraath, P., et al. (2020). Coronavirus Disease 2019 (COVID-19) Pandemic and Pregnancy. The American Journal Obstetrics \& Gynecology, 222(6), 521-531.

Favre, G., et al. (2020). Guidelines for pregnant women with suspected SARS-CoV-2 infection. The Lancet Infectious Disease, 3099(20), 30157.

Iqbal, S.N., et al. (2020). An uncomplicated delivery in a patient with COVID-19 in the United States. The New England Journal of Medicine, 683-684.

Korraa, A.A. (2020). Management of Neonates Born to Mothers with COVID-19. Annals of Neonatology Journal, 2(2).

Liu, D., et al. (2020). Pregnancy and perinatal outcomes of women with coronavirus disease (COVID-19) pneumonia: a preliminary analysis. American Journal Roentgenology, 1-6.

Perkumpulan Obstetri dan Ginekologi Indonesia. (2020). Rekomendasi Penanganan Infeksi Virus Corona (COVID-19) pada Maternal (Hamil, Bersalin, dan Nifas). Pokja Infeksi
Saluran Reproduksi POGI. Dari : https://pogi.or.id/publish/wpcontent/uploads/2020/03/Rekome ndasi-Penanganan-Infeksi-COVID19-pada-maternal.pdf, diunduh pada tanggal 29 Juni 2020.

Queensland Government. (2020). Queensland Clinical Guidelines: Maternity care for mothers and babies during the COVID-19 pandemic, COVID-19 and breastfeeding Guideline No. MN20.63-V2-R25. Queensland, The State of Queensland. Dari : www.health.qld.gov.au/qcg, dilihat pada tanggal 13 Juli 2020.

Royal College of Obstetricians and Gynaecologists. (2020). Coronavirus (COVID-19) infection in pregnancy: information for healthcare professionals V4. London, Royal College of Obstetricians and Gynaecologists. Dari : https://www.rcog.org.uk, dilihat pada tanggal 13 Juli 2020.

Team Novel Coronavirus Pneumonia Emergency Response Epidemiology Team. (2020). Vital surveillances: the epidemiological characteristics of an outbreak of 2019 novel coronavirus diseases (COVID-19) in China. China CDC Weekly, 41(2), 145-151.

World Health Organization. (2020). Tatalaksana klinis infeksi saluran pernapasan akut berat (SARI) suspek penyakit COVID-19, 4, 125.

Zhu, H., et al. (2020). Clinical analysis of 10 neonates born to mothers with 2019-nCoV pneumonia. Translational Pediatrics, 9(1), 5160. 